Nippon Suisan Gakkaishi $\quad$ 77(5), 931-933 (2011)

東日本大震災による水産業の被害実態と復興の足がかり

三重県における水産業の被害実態と再生への取り組み

松田浩一

三重県水産研究所

\section{1. 三重県沿岸における津波の状況}

平成 23 年 3 月 11 日に発生した東北地方太平洋沖地 震に伴って発生した津波によって三重県でも大きな漁業 被害が発生しました。もちろん, 未曾有の被害を受けた 東北地方とは比較のしようもありませんが，三重県にお ける近年の自然災害による漁業被害としてはかなり大き なものでした。

東北地方太平洋沖地震よる津波が三重県の沿岸に到達 したのは, 地震発生後およそ 2 時間前後のことでした が，最大波の到達は 2 時間後から 6 時間後と地域によ って大きな違いがありました。図 1 に三重県鳥羽市に おける平成 23 年 3 月 11 日 12 時から 13 日 12 時までの 15 秒間隔での天文潮位（潮汐力の久を想定した予測潮 位）と潮位偏差 (天文潮位と実測潮位の差) を示します。 鳥羽市では, 地震発生の 2 時間 9 分後に津波の第 1 波 が到達しており，その高さは約 $50 \mathrm{~cm}$ でした。鳥羽市 に到達した最大波の高さは $170 \mathrm{~cm}$ であり, 地震発生の 4 時間 29 分後の第 5 波でした。津波はその後も 30 分か ら 1 時間間隔で絶え間なく到達し, 波高は次第に低く なりながらも, 数日間継続しました。鳥羽市に最大波が 到達した時は, 天文潮位が $271 \mathrm{~cm}$ (大潮の干潮面を基
準）と比較的高くなっている時であり, 最大波が到達し た時の実際の潮位は $441 \mathrm{~cm}$ とかなり高く, 潮流の速さ も大きかったと推察されます。

また, 津波は地震発生後 24 時間で 40 波以上が到達 しており, 繰り返し到達する引き波と押し波によって内 湾域では潮流の流れが複雑になり, 湾によっては大きな 渦の発生が確認されています。この渦によって, 漁業施 設が大きな被害を受けたことが目撃されています。

\section{2. 三重県における漁業被害の状況}

東日本大震災に関連した三重県における漁業被害は, 40 億 8 千万円と算定されており（三重県農水商工部調 べ, 平成 23 年 5 月末現在), すべて津波による被害で す（表1)。津波による被害であることから, 沿岸域に 固定して利用寸る漁業施設に多くの被害が発生して打 り, 特に魚類養殖, カキ養殖, 藻類養殖（黒ノリ, 青ノ リ), 真珠養殖などの養殖施設や養殖生産物への被害が 全体の 9 割を占めています (図 2)。養殖関係以外では, 定置網に多くの被害が見られました。

魚類養殖の被害は大きく 2 つに区分され, 施設の損 傷とそれによる養殖魚の圧死・逃亡など震災当日に発生

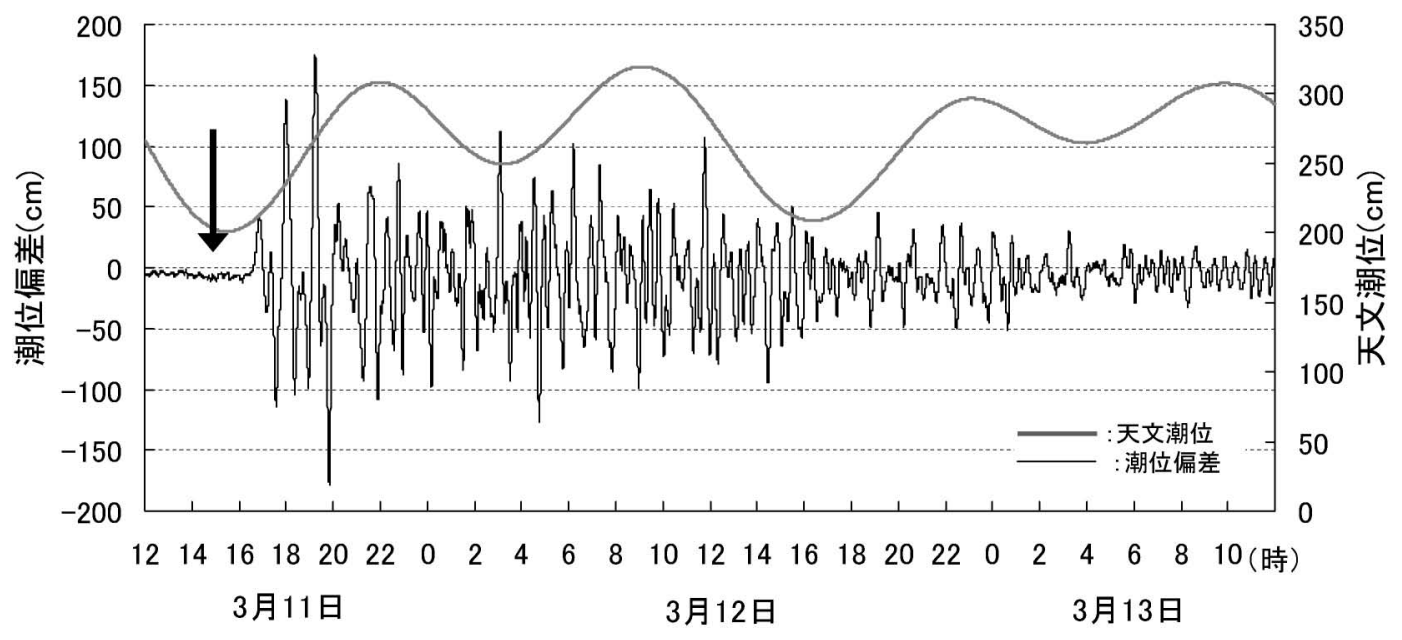

図 1 東北地方太平洋沖地震の発生前後における三重県鳥羽市の天文潮位（大潮の干潮時を基準とした值），抢よび天文潮位と実 測潮位の差を示す潮位偏差

ともに 15 秒間隔の值。矢印は地震発生時刻。データは津気象台の好意による提供による。 
表 1 今回の津波による三重県に抢ける漁業被害

\begin{tabular}{cc}
\hline \multicolumn{1}{c}{ 内 容 } & 被害金額 \\
\hline 水産養殖物・養殖施設 & \\
魚類養殖 (マダイ・クロマグロ等 $)$ & 16 億 3 千万円 \\
カキ養殖 & 10 億 7 千万円 \\
海藻類養殖 (黒ノリ, 青ノリ等 $)$ & 7 億 1 千万円 \\
真珠養殖業 & 3 億円 \\
合 計 & 37 億 1 千万円 \\
\hline 漁具・漁船 & 3 億 5 千万円 \\
漁具 (定置網) & 2 千万円 \\
漁船 & 3 億 7 千万円 \\
合 計 & 40 億 8 千万円 \\
\hline 総 額
\end{tabular}

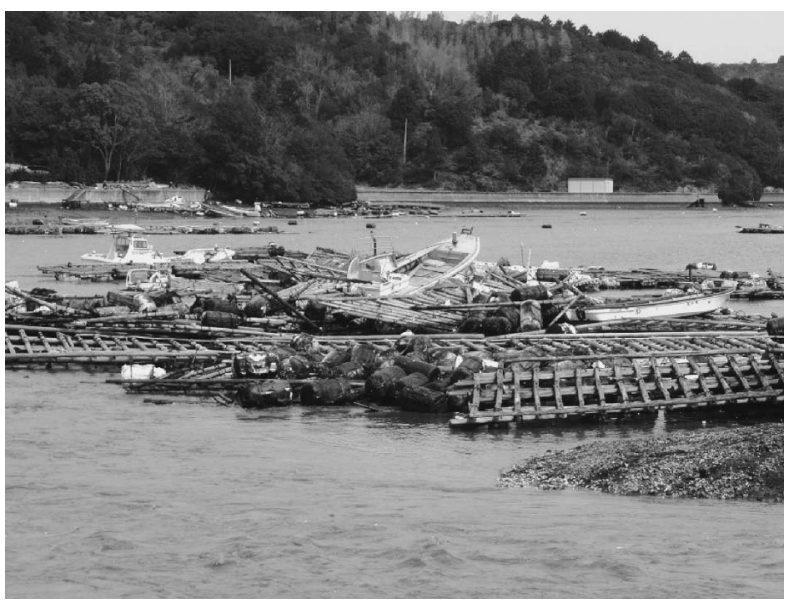

図 2 津波による三重県のマガキ養殖の被災状況（伊勢 農林水産商工環境事務所水産室撮影）

筏が重なり，その上に漁船が乗り上げている。

したもの，繰り返し到達した津波によると考えられるス レやストレスによる衰弱死など数日以内に発生したもの がありました。また，マダイを中心とした養殖魚に打い て震災後の 3 月から 5 月にシュードモナス病が多発 し，へい死率が 10～20\%に達する場合も見られまし た。これも津波による影響と推察されます。力キ養殖, 真珠養殖, 藻類養殖の被害では, 養殖施設の損傷と養殖 物の流出, 脱落によるものでした。力キ養殖や黒ノリ,

青ノリ養殖では, 生産のピークが過ぎていたことは不幸 中の幸いでした。

被害が発生した地域は, 三重県中南部地域を中心とし た伊勢湾から熊野灘沿岸の 10 市町に及び，養殖業が盛 んな伊勢湾, 英盧湾, 五ヶ所湾などで被害が集中してい ます。

三重県では, 平成 22 年 2 月 7 日にもチリ津波（最大 波高は $60 \sim 70 \mathrm{~cm}$ ）による漁業被害が発生しており，こ の時においても養殖業を中心に 2 億 6 千万円の被害が
発生しました。このように, 三重県では 2 年続けての 津波被害に見舞わ秃, 漁業を取り巻く環境は一層厳しい ものとなっています。

\section{3. 三重県における漁業再生への取り組み}

今回の津波被害に対して三重県では, 被災した施設や へい死した養殖生産物の撤去を迅速に行うとともに, 養 殖施設や定置網などの復旧を支援する事業を緊急に実施 して抢り，震災後 4 ヶ月が経過してようやく漁業を再 開する体制が整いつつあります。しかし，震災直後から 問題となっている課題がありました。それは, マガキ養 殖業への支援です。三重県でのマガキ養殖では，多くの 生産者が宮城県で生産された種苗を用いています。水温 が低い東北地方で生産された種苗を三重県で養殖すると マガキの成長が早く，秋に宮城県から移送された種苗は 翌年の秋には出荷サイズに達し，出荷することができま す。このビジネスモデルは効率的で，収益性も高くなる ことから, 三重県でのマガキ種苗の生産は一部の海域で 限定的に行われているだけでした。しかし，今回の震災 によって宮城県のマガキの生産施設が大きな被害を受 け, 三重県への種苗供給が絶望視されました。最近, 東 北地方で生産者の多大な努力によりマガキ種苗の生産が 再開されるという明るい話も報道されていますが，それ にしても供給量が震災前の水準に戻るには時間がかかる と思います。この事態に対して, 三重県水産研究所では マガキ種苗を生産する技術を導入し, 試験的に種苗生産 を行うための緊急的な取り組みを実施することとしまし た。養殖に用いる種苗を単一の産地で生産されたものに 頼っていると, 今回の震災のようにその産地の施設が被 害を受けた場合には種苗の確保が困難となります。ま た, 種苗を他県の海域から購入する際には, 疾病や有害 赤潮の持込みの危惧もあります。安定した生産のために は, リスク分散のために種苗の導入ルートを複数確保す ることが必要であり，そのためには三重県で独自に種苗 生産を行う技術を保持しておくことが不可欠と考えてい ます。

マガキ種苗の生産は宮城県を始めとして, 広島県や兵 庫県などでも行われており，技術的には確立されたもの になっていますが, 三重県水産研究所ではマガキ種苗の 生産実績がないことから, 取り組みにあたっては三重県 内で水産研究を行っている三重大学大学院生物資源学研 究科々独水産総合研究センター増養殖研究所へ協力の要 請を行いました。増養殖研究所からは, 震災発生の直後 から震災対応の研究に対する支援の申し出を頂いていま したし, 三重大学大学院でも震災を受けた県内の漁業へ の支援を検討しておられたことから，協力の要請に快く 応じていただき, マガキ共同研究チームを立ち上げて実 施することになりました。 


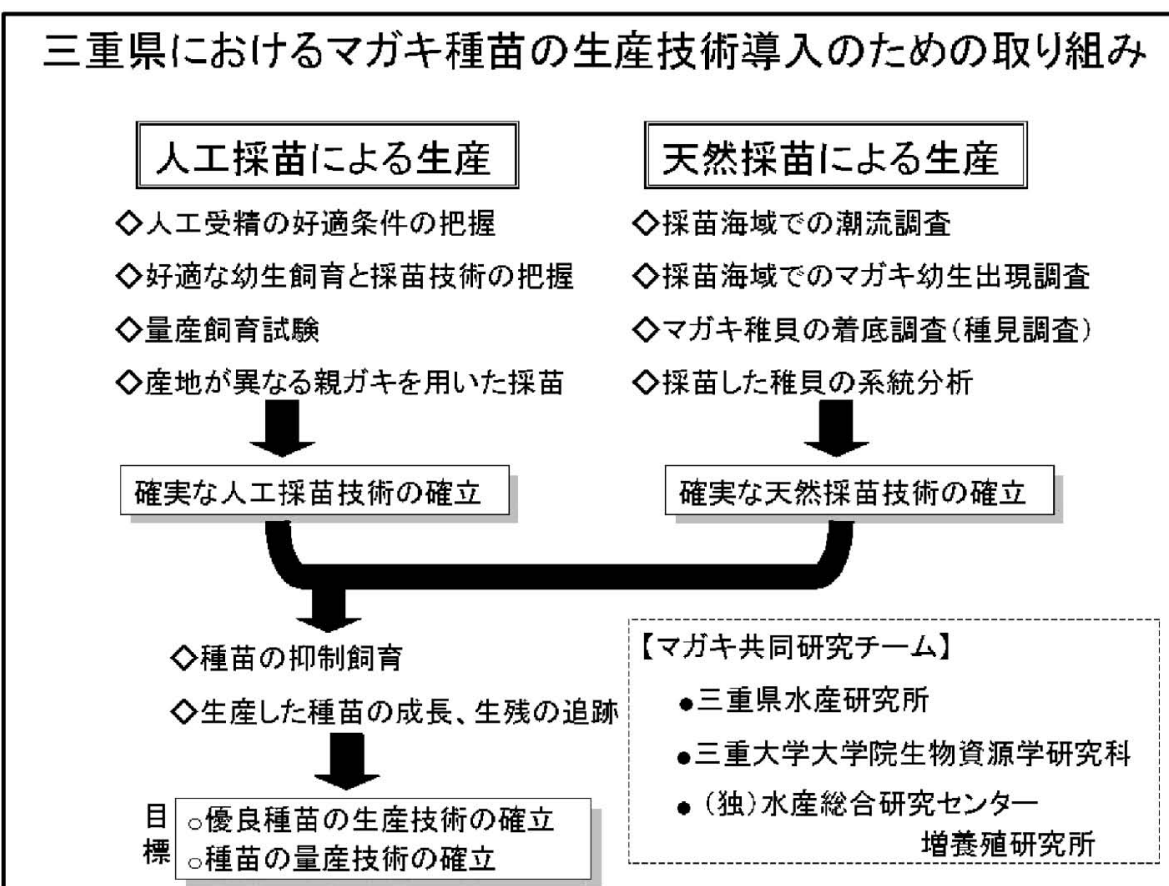

図 3 三重県に抢けるマガキ養殖を支援するためのマガキ共同研究チームの取り組み内容

取り組みの内容は, 人工採苗と天然採苗の技術の導入 で（図 3 ），人工採苗は宮城県の種苗を育成して得たマ ガキを親ガキとして用い，優良な形質を持つ種苗を生産 することを目的としており, 天然採苗は種苗の量産を目 的としています。取組にあたっては，3つの研究機関で 役割分担や共同調查を行い，連携して進めています。地 元の漁業を支援することを重視した取り組みを, 三重県 にある研究機関が連携して行うことは初めてのことであ り，この取り組久を是非成功させたいと考えています。

実は, 三重県と三重大学大学院生物資源学研究科, 増 養殖研究所では, 平成 21 年度から三重地域産学官連携 水産研究連絡会議を組織し, 三重県の漁業を支援するた めの共同の取り組みを始めていました。これまでも共同 で立案した研究課題の競争的研究資金への応募や，合同 成果報告会の開催を行っています。この連絡会議での活 動が, 今回のマガキ共同研究チームの円滑な立ち上げ
と, 共同研究の実施に繋がっています。今回の津波によ る被害が大きかった魚類養殖に対しても, 連絡会議では 生産者とともに研究フォーラムを開催し, 震災に強い養 殖や新しい養殖形態の提案などの講演と, 三重県に打け る今後の魚類養殖のあり方などについても意見交換を行 いました。こういった取り組久が, 水産研究機関と生産 者の距離を縮め, 厳しい状況にある三重県の漁業への支 援になることを期待しています。

三重県では, いつ発生しても扔かしくないとされてい る東海地震, 今後 30 年の間の発生確率が $70 \%$ 程度と されている東南海地震, 同じく $60 \%$ 程度とされている 南海地震による震災が予想されます。このような巨大地 震に施設面から備えることは不可能ですが，どのような 災害に対しても必ず復興できることを信じて，まずは東 日本太平洋沿岸の漁業再生への取組を支援していくこと が重要と考えています。 